\title{
PENERAPAN MODEL PEMBELAJARAN TEAM ASSISTED INDIVIDUALIZATION BERBANTUAN LEMBAR KERJA SISWA DALAM UPAYA MENINGKATKAN KUALITAS PROSES DAN HASIL BELAJAR MATEMATIKA SISWA MTS
}

\author{
AGUS SUSILO \\ MTs Al Falahiyah \\ SUPARDI U.S. \\ Program Pascasarjana, Universitas Indraprasta PGRI
}

\begin{abstract}
Abstrak. Penelitian bertujuan untuk meningkatkan kualitas proses dan hasil belajar matematika siswa kelas VIII MTs melalui penerapan model pembelajaran Team Assisted Individualization. Metode penelitian yang digunakan adalah metode penelitian tindakan kelas (PTK) sebanyak tiga sikulus. Alur pelaksanaan setiap siklus yaitu perencanaan, pelaksanaan, pengamatan, refleksi dan dilanjutkan perencanaan tindakan berikutnya. Subyek penelitian terdiri atas 30 siswa kelas VIII. Instrumen penelitian berupa lembar pengamatan keterlibatan siswa dalam pembelajaran, aktivitas diskusi kelompok, kinerja guru, serta skala penilaian sikap siswa pada pembelajaran matematika dan tes hasil belajar matematika. Hasil penelitian dengan menerapkan model pembelajaran Team Assisted Individualization, diperoleh temuan tentang kualitas proses dan hasil belajar matematika siswa sebagai berikut: (1) Rata-rata hasil pengamatan keterlibatan siswa dalam belajar pada siklus I 52,5\%, siklus II 65\% dan siklus III 75\%; (2) Rata-rata hasil pengamatan aktivitas diskusi kelompok pada siklus I 46.78\%, siklus II 59,12\% dan siklus III 60\%; (3) Rata-rata hasil pengamatan kinerja guru pada siklus I $41,87 \%$, siklus II $60 \%$ dan siklus III 68,75\%; (4) Rata-rata sikap siswa pada pembelajaran matematika mengalami peningkatan yaitu pada siklus I 73\%, siklus II 76\% dan siklus III 73,67\%; (5) Rata-rata hasil belajar matematika mengalami peningkatan yaitu pada siklus I 51,5\%, siklus II 74,44\%, siklus III 83,33\%. Berdasarkan hasil temuan tersebut, dapat disimpulkan bahwa penerapan model pembelajaran Team Assisted Individualization dapat meningkatkan kualitas proses dan hasil belajar matematika siswa untuk materi aljabar.
\end{abstract}

Kata Kunci: matematika, model pembelajarna, hasil belajar, teacm assisted individualization

\section{PENDAHULUAN}

Pendidikan merupakan proses untuk membantu manusia dalam mengembangkan potensi dirinya sehingga mampu menghadapi setiap perubahan yang terjadi dalam kehidupan. Upaya peningkatan mutu pendidikan terus dilakukan untuk mendapatkan hasil pendidikan yang baik serta peningkatan sumber daya manusia. Oleh karena itu pendidikan perlu mendapatkan perhatian dalam penanganannya baik dari pemerintah, masyarakat, dan pengelola pendidikan itu sendiri.

Peranan guru sangat penting dalam pendidikan. Seorang guru harus memiliki dan mampu menerapkan strategi tertentu supaya siswa dapat belajar secara efektif. Setiap siswa memiliki potensi yang perlu dikembangkan. Tindakan atau perilaku belajar dapat diatur dan berjalan sesuai dengan karakteristik masing-masing siswa. Perbedaan siswa inilah yang harus diperhatikan oleh seorang guru dalam menerapkan model pembelajaran yang sesuai, sehingga guru dapat mengetahui sejauh mana siswa dapat memahami materi pelajaran yang diberikan. 
Mata pelajaran yang sukar, biasanya memerlukan konsentrasi yang tinggi dan untuk saat ini mata pelajaran yang dianggap sukar oleh sebagian siswa adalah pelajaran matematika. Saat ini masih banyak siswa yang mengalami kesulitan belajar matematika, karena matematika masih dianggap suatu pelajaran yang menakutkan, penuh angka dan rumus. Selain itu, masih adanya sistem belajar yang menyamaratakan kemampuan siswa, saat siswa belum menguasai materi dasar, sudah ditambah dengan materi lain.

Dalam pelajaran matematika terdapat pokok bahasan faktorisasi aljabar yang dipelajari di kelas VIII semester I. Ada beberapa kendala yang dihadapai dalam pelaksanaan proses belajar-mengajar pokok bahasan ini. Beberapa diantaranya adalah siswa kurang memahami konsep materi faktorisasi aljabar dan suasana pembelajaran yang cenderung kaku karena komunikasi lebih banyak didominasi oleh guru. Adanya kendala tersebut menjadi faktor yang mempengaruhi hasil belajar siswa pada mata pelajaran matematika. Oleh karena itu diperlukan suatu tindakan untuk memperbaiki proses pembelajaran dan diharapkan terjadinya peningkatan hasil belajar.

Salah satu usaha guru agar keberhasilan siswa dapat tercapai adalah dengan menerapkan model pembelajaran Team Assisted Individualization berbantuan Lembar Kerja Siswa (LKS). Dalam Salim's ninth Collegiate English-Indonesian Dictionary Team dalam bahasa Indonesia adalah kelompok, Assisted adalah membantu, sedangkan individual adalah perseorangan. Jadi Team Assisted Individualization artinya bantuan terhadap individu atau perseorangan dalam pembelajaran kelompok.

Model pembelajaran Team Assisted Individualization termasuk dalam pembelajaran kooperatif. "Pembelajaran kooperatif merujuk pada berbagai macam metode pengajaran dimana para siswa belajar dalam kelompok-kelompok kecil untuk saling membantu dalam mempelajari materi pelajaran"(Slavin, 2010:4). Salah satu ciri pembelajaran kooperatif adalah kemampuan siswa untuk bekerja sama dalam kelompok kecil yang heterogen. Model pembelajaran Team Assisted Individualization merupakan model pembelajaran yang mempunyai strategi pembelajaran penerapan bimbingan antar teman. "Dasar pemikiran dalam pembelajaran ini adalah untuk mengadaptasi pengajaran terhadap perbedaan individual berkaitan dengan kemampuan siswa”( Slavin, 2010:187).

Melalui model pembelajaran Team Assisted Individualization siswa diajak belajar mandiri, dilatih untuk mengoptimalkan kemampuannya dalam menyerap materi pelajaran, dilatih untuk menjelaskan temuannya kepada pihak lain dan dilatih untuk memecahkan masalah. Jadi melalui model pembelajaran ini siswa diajak berpikir dan memahami materi tidak hanya mendengar, menerima dan mengingat-ingat saja. Namun dengan model pembelajaran ini keaktifan, kemandirian dan keterampilan siswa dapat dikembangkan dan akhirnya pemahaman konsep yang diperoleh dapat berkembang secara efektif.

Berdasarkan paparan di atas sehingga timbul permasalahan: Apakah melalui penerapan model pembelajaran Team Assisted Individualization berbantuan lembar kerja siswa dapat meningkatkan kualitas proses dan hasil belajar matematika untuk pokok bahasan faktorisasi aljabar?

Selanjutnya, melalui pemecahan masalah tersebut diharapkan dapat memberikan manfaat baik secara teoretik maupun praktik pendidikan. Secara teoretik diharapkan dapat memberikan kontribusi dalam pengembangan ilmu yang terkait dengan upaya-upaya peningkatan kualitas pendidikan, khususnya dalam pembelajaran matematika. Secara praktik, diharapkan hasil penelitian ini memberikan masukan bagi para guru/pendidik atau pemerhati pendidikan lainnya dalam upaya melakukan inovasi-inovasi pembelajaran sehingga mengahaslkan proses pembelajaran matematika yang efektif. 


\section{TINJAUAN PUSTAKA}

\section{Hasil Belajar Matematika}

Dimyati dan Mudjiono (2006:18) mengatakan "Belajar merupakan proses internal yang kompleks, yang telibat dalam proses tersebut adalah seluruh mental yang meliputi ranah-ranah kognitif, afektif dan psikomotorik." Djamarah (2002:13) menyimpulkan bahwa Belajar adalah serangkaian suatu perubahan tingkah laku sebagai hasil dan pengalaman individu dalam interaksi dengan lingkungannya yang menyangkut kognitif, afektif, dan psikomotorik." Hilgard dan Bower, dalam Purwanto (2004:84) mengemukakan "Belajar berhubungan dengan perubahan tingkah laku seseorang terhadap sesuatu situasi tertentu yang disebabkan oleh pengalamannya yang berulang-ulang dalam situasi itu, dimana perubahan tingkah laku itu tidak dapat dijelaskan atau dasar kecenderungan respon pembawaan, kematangan atau keadaan-keadaan sesaat seseorang." Menurut Syah (2004:64) "Belajar dapat dipahami sebagai tahapan perubahan seluruh tingkah laku individu yang relatif menetap sebagai hasil pengalaman dan interaksi dengan lingkungan yang melibatkan proses kognitif." Sedangkan Yamin (2005:99) mengemukakan "Belajar adalah perubahan perilaku seseorang akibat pengalaman yang didapat melalui pengamatan, pendengaran, membaca, dan meniru." Oleh karenanya dapat disimpulkan bahwa belajar adalah suatu proses yang dilakukan seseorang untuk memperoleh suatu perubahan tingkah laku yang baru secara keseluruhan sebagai hasil pengalamannya sendiri dalam interaksi dengan lingkungannya.

Sudjana (2009: 22) mengemukakan, hasil belajar adalah kemampuankemampuan yang dimiliki peserta didik setelah menerima pengalaman belajarnya. Selanjutnya, Syah, Supardi dan Muslihah (2009: 15-16) mengatakan "Hasil belajar dapat ditunjukkan dalam berbagai bentuk, seperti perubahan pengetahuan, pemahaman, sikap dan perilaku, kecakapan, kebiasaan, dan perubahan-perubahan aspek lain yang ada pada individu yang belajar". Perubahan tingkah laku yang didapat siswa setelah mengikuti proses belajar dapat berbentuk pengetahuan (kognitif), sikap, perilaku dan kebiasaan (afektif) maupun keterampilan (skill). Suryanto, dkk (2009: 4.3) mengatakan, aspek yang harus diukur dalam penilaian hasil belajar meliputi: aspek kognitif, afektif atau psikomotor. Kirkpatrick (2006: 46) mengatakan "This evaluation of learning is important for two reasons. First, it measures the effectiveness of the instructor in increasing knowledge and/or changing attitudes. It shows how effective he or she is." Penilaian hasil belajar ini adalah penting untuk dua buah alasan. Pertama, untuk mengukur efektifitas pembelajaran dalam rangka meningkatkan pengetahuan (aspek kognitif), dan kedua, untuk mengukur perubahan sikap (aspek afektif). Hal ini menunjukkan keefektipan seseorang dalam belajar. Dengan demikian dapat disimpulkan, hasil belajar adalah pola-pola perubahan tingkah laku seseorang yang meliputi aspek kognitif, afektif dan/atau psikomotor setelah menempuh kegiatan belajar tertentu yang tingkat kualitas perubahannya sangat ditentukan oleh faktor-faktor yang ada dalam diri siswa dan lingkungan sosial yang mempengaruhinya. Perubahan tingkah laku merupakan wujud hasil belajar seseorang setelah mempelajari sesuatu objek. Jika objeknya Matematika, maka perubahan tingkah laku tersebut yaitu perubahan pengetahuan, sikap, minat, kecenderungan atau tindakan yang terkait dengan Matematika.

Secara etimologis, Matematika adalah ilmu tentang bilangan, hubungan antara bilangan dan prosedur operasional yang digunakan adalah penyelesaian masalah menjadi bilangan. Alwi (2002:723) menyatakan "Matematika didefinisikan sebagai ilmu tentang bilangan, hubungan antara bilangan dan prosedur operasional yang digunakan dalam penyelesaian masalah bilangan." Russefendi (1990:149) mengemukakan bahwa "Matematika terbentuk sebagai hasil pemikiran manusia yang berhubungan dengan ide, proses, dan penalaran." Sedangkan Hudoyo (1988:74) mengemukakan bahwa 
"Matematika adalah ilmu pengetahuan mengenai kuantiti, teori logika deduktif, penelaahan tentang struktur, ide-ide atau konsep abstrak yang tersusun secara hirarkis dan penalarannya deduktif. Berdasarkan uraian tersebut dapat disimpulkan bahwa matematika adalah ilmu yang mempelajari tentang bilangan dan opersional bilangan dalam penyelesaian masalah dengan cara penalaran logis yang memiliki nilai praktis, dengan obyek berupa ide atau konsep abstrak yang tersusun secara hirarkis yang diwujudkan dalam bentuk simbol-simbol serta penalarannya yang bersifat deduktif.

\section{Proses Pembelajaran Matematika}

\section{a. Aktivitas belajar}

Dalam belajar diperlukan aktivitas sebab pada prinsipnya belajar adalah berbuat, berbuat untuk mengubah tingkah laku jadi melakukan kegiatan. Tidak ada belajar kalau tidak ada aktivitas. Itulah sebabnya aktivitas merupakan prinsip atau asas yang sangat penting di dalam interaksi belajar mengajar. Montessori dalam Sardiman (1986:95) mengatakan "Yang lebih banyak melakukan aktivitas dalam pembentukan diri adalah anak itu sendiri, sedangkan pendidik memberikan bimbingan dan merencanakan segala kegiatan yang akan diperbuat oleh anak didik." Sardiman (1986:98) mengatakan "aktivitas belajar itu adalah aktivitas yang bersifat fisik maupun mental." Dalam kegiatan belajar kedua aktivitas itu harus selalu berkait. Sebagai contoh seseorang sedang belajar dengan membaca, secara fisik kelihatan bahwa dia sedang membaca tetapi mungkin pikiran dan sikap mentalnya tidak tertuju pada buku yang dibaca. Jenis-jenis aktivitas belajar menurut Diedrich dalam Sardiman (1986:99): “(1) Visual activities seperti membaca, memperhatikan gambar, (2) oral activities seperti menyatakan, merumuskan, bertanya, mengeluarkan pendapat dan diskusi, (3) listening activities seperti mendengarkan, (4) writing activities seperti menulis, membuat lapaoran, (5) drawing activities seperti menggambar, membuat grafik, dan peta, (6) motor activities seperti melakuakan percobaan, mereparas, (7) mental activities seperti mengingat, menganalisa, mengambil keputusan, dan (8) emotional activities seperti minat, gembira, bersemangat, berani, tenang dan gugup." Dari uraian diatas dapat disimpulkan bahwa aktivitas belajar adalah bentuk-bentuk perbuatan yang dilakukan oleh peserta didik untuk mengubah tingkah laku yang bersifat fisik maupun mental dalam kegiatan belajar.

\section{b. Motivasi belajar}

Menurut Hamalik (2010:158) "Motivasi adalah perubahan energi dalam diri pribadi seseorang yang ditandai dengan timbulnya perasaan dan reaksi untuk mencapai tujuan." Eysenck dalam Slameto (2010:170) "merumuskan motivasi sebagai suatu proses yang menentukan tingkatan kegiatan, intensitas, konsistensi, serta arah umum dari tingkah laku manusia." Sedangkan Maslow dalam Slameto (2010:171) "mengemukakan bahwa tingkah laku manusia dibangkitkan dan diarahkan oleh kebutuhan-kebutuhan yang memotivasi tingkah laku seseorang." Motivasi dapat bersifat intrinsik yaitu datang dari diri sendiri dan ekstrinsik yaitu datang dari orang lain seperti guru, teman dan orang tua. Fungsi motivasi dapat mendorong timbulnya kelakuan atau suatu perbuatan, mengarahkan pada pencapaian tujuan dan menentukan cepat lambatnya suatu pekerjaan.

Didalam kegiatan peembelajaran peranan motivasi sangat diperlukan untuk mengembangkan aktivitas dan inisiatif siswa. Sardiman (1986:91) mengemukakan, "Ada beberapa petunjuk dan cara untuk menumbuhkan motivasi siswa dalam kegiatan belajar mengajar disekolah : (1) memberi angka, (2) memberi hadiah, (3) Saingan atau kompetisi antar siswa, (4) menumbuhkan kesadaran kepada siswa untuk belajar, (5) memberi ulangan, (6) memberitahu hasil pekerjaannya, (7) memberi pujian, (8) memberi hukuman, (9) membangkitkan hasrat untuk belajar, (10) minat, (11) tujuan yang diakui dan diterima 
baik oleh siswa." Dari uraian diatas dapat disimpulkan bahwa motivasi belajar adalah perubahan energi dalam diri pribadi seseorang yang ditandai dengan timbulnya perasaan dan reaksi sebagai suatu proses yang menentukan tingkatan kegiatan, intensitas, konsistensi, serta arah umum yang dibangkitkan dan diarahkan oleh kebutuhankebutuhan.

\section{Model Pembelajaran Team Asissted Individualization}

Soekamto dalam Trianto (2010:22) menyatakan "Model pembelajaran adalah kerangka konseptual yang melukiskan prosedur yang sistematis dalam mengorganisasikan pengalaman belajar untuk mencapai tujuan belajar tertentu dan berfungsi sebagai pedoman bagi para perancang pembelajaran dan para pengajar dalam merencanakan aktivitas belajar mengajar." Slavin dalam Trianto (2010:56) menyatakan, bahwa dalam belajar kooperatif siswa dibentuk dalam kelompok-kelompok yang terdiri dari 4 atau 5 siswa untuk bekerja sama dalam menguasai materi yang diberikan guru. Pembelajaran kooperatif dilakukan dengan tujuan untuk memaksimalkan belajar siswa dalam upaya peningkatan prestasi akademik dan pemahaman baik secara individu maupun secara kelompok. Ada beberapa variasi dalam model pembelajaran kooperatif, yaitu diantaranya: a) STAD (Student Teams Achievement Divisions), b) TGT (Teams Games Tournament), c) TAI (Teams Assisted Individualization), d) Jigsaw, e) CIRC (Cooperative Integrated Reading and Composition), f) TPS (Think Pair Share), dan g) NHT (Numbered Head Together).

Model pembelajaran Team Assisted Individualization termasuk dalam pembelajaran kooperatif. Dalam model pembelajaran Team Assisted Individualization, siswa ditempatkan dalam kelompok-kelompok kecil (4 sampai 5 siswa) yang heterogen untuk menyelesaikan tugas kelompok yang sudah disiapkan oleh guru. Selanjutnya diikuti dengan pemberian bantuan secara individu bagi siswa yang memerlukannya. Keheterogenan kelompok mencakup jenis kelamin, ras, tingkat kemampuan (tinggi, sedang, rendah) dan sebagainya. Slavin (2010:195) mengemukakan bahwa model pembelajaran Team Assisted Individualization dirancang untuk menyelesaikan masalahmasalah teoritik dan praktik dari sistem pengajaran individual. Model pembelajaran Team Assisted Individualization memiliki 8 (delapan) unsur program, meliputi: 1) Teams yaitu pembentukan kelompok heterogen yang terdiri dari 4 sampai 5 siswa. 2) Placement Test yaitu pemberian pre-test kepada siswa atau melihat rata-rata nilai harian siswa agar guru mengetahui kelemahan siswa pada bidang tertentu. 3) Student Creative yaitu melaksanakan tugas dalam suatu kelompok dengan menciptakan dimana keberhasilan individu ditentukan oleh keberhasilan kelompoknya. 4) Team Study yaitu tahapan tindakan belajar yang harus dilaksanakan oleh kelompok dan guru memberikan bantuan secara individual kepada siswa yang membutuhkan. 5) Team Score and Team Recognition yaitu pemberian skor terhadap hasil kerja kelompok dan memberikan kriteria penghargaan terhadap kelompok yang berhasil secara cemerlang dan kelompok yang dipandang kurang berhasil dalam menyelesaikan tugas. 6) Teaching Group yaitu pemberian materi secara singkat dari guru menjelang pemberian tugas kelompok. 7) Fact test yaitu pelaksanaan tes-tes kecil berdasarkan fakta yang diperoleh siswa. 8) WholeClass Units yaitu pemberian materi oleh guru kembali diakhiri waktu pembelajaran dengan strategi pemecahan masalah.

Adapun tahap-tahap dalam model pembelajaran Team Assisted Individualization sebagai berikut. 1) Guru menyiapkan materi bahan ajar yang akan diselesaikan oleh kelompok siswa. 2) Guru memberikan pre-test kepada siswa atau melihat rata-rata nilai harian siswa agar guru mengetahui kelemahan siswa pada bidang tertentu. (Mengadopsi komponen Placement Test). 3) Guru memberikan materi secara singkat. (Mengadopsi 
komponen Teaching Group). 4) Guru membentuk kelompok kecil yang heterogen tetapi harmonis berdasarkan nilai ulangan harian siswa, setiap kelompok $4-5$ siswa. (Mengadopsi komponen Teams). 5) Setiap kelompok mengerjakan tugas dari guru berupa LKS yang telah dirancang sendiri sebelumnya, dan guru memberikan bantuan secara individual bagi yang memerlukannya. (Mengadopsi komponen Team Study). 6) Ketua kelompok melaporkan keberhasilan kelompoknya dengan mempresentasikan hasil kerjanya dan siap untuk diberi ulangan oleh guru. (Mengadopsi komponen Student Creative). 7) Guru memberikan post-test untuk dikerjakan secara individu. (Mengadopsi komponen Fact Test). 8) Guru menetapkan kelompok terbaik sampai kelompok yang kurang berhasil (jika ada) berdasarkan hasil koreksi. (Mengadopsi komponen Team Score and Team Recognition). 9) Guru memberikan tes formatif sesuai dengan kompetensi yang ditentukan.

Dengan demikian dapat disimpulkan bahwa model pembelajaran Team Assisted Individualization adalah model pembelajaran bantuan terhadap individu dalam pembelajaran kelompok dan dilakukan dengan cara mengadaptasi pengajaran terhadap perbedaan individu, supaya keaktifan, kemandiriran dan ketrampilan siswa dapat dikembangkan dengan harapan agar tujuan pembelajaran dapat tercapai.

\section{METODE}

Penelitian dilakukan pada siswa kelas VIII A sebanyak 30 siswa pada semester ganjil 2011/2012 di Madrasah Tsanawiyah Al-Falahiyah, di Desa Kemuning Kecamatan Kresek, Kabupaten Tangerang. Metode penelitian yang digunakan yaitu metode penelitian tindakan kelas (PTK) atau Classroom Action Research, sebanyak 3 (tiga) siklus. Masing-masing siklus dilaksanakan dalam empat tahap, yaitu perencanaan, tindakan, pengamatan, dan refleksi. Penelitian ini dilakukan oleh peneliti dan dibantu oleh guru yang bertindak sebagai pengajar dan pengamat.

Data yang dikumpulkan dan dianalisis dalam penelitian ini meliputi: (1) Aktivitas diskusi kelompok, (2) Keterlibatan siswa dalam pembelajaran matematika, (3) Sikap siswa terhadap pembelajaran matematika, (4) Persepsi Siswa pada kinerja guru dalam pengelolaan pembelajaran, dan (5) hasil belajar matematika yang meliputi pemahaman konsep, penalaran dan komunikasi serta pemecahan masalah yang berkaitan dengan materi faktorisasi aljabar.

Analisis data dilakukan dengan pendekatan deskriptif-naratif untuk data kualitatif, dan pendekatan statistika deskriptif untuk data kuantitatif. Pengujian hipotesis tindakan dilakukan melalui pendekatan evaluasi dengan kriteria atau indikator keberhasilan sebagai kerikut: (1) Aktivitas siswa dalam diskusi kelompok belajar matematika dikatakan berhasil apabila rata-rata siswa yang minimal aktif dalam belajar mencapai persentase $\geq 62,5 \%$; (2) Keterlibatan siswa dalam pembelajaran dikatakan berhasil apabila rata-rata siswa yang memiliki kategori minimal baik mencapai $\geq 62,5 \%$; (3) Sikap siswa terhadap pembelajaran matematika dikatakan berhasil apabila rata-rata hasil kuisioner siswa yang minimal merasa senang terhadap pembelajaran menunjukkan nilai $\geq 70 \%$; (4) Persepsi siswa pada kinerja guru dalam pengelolaan kelas dinilai berhasil, apabila rata-rata siswa yang menilai minimal baik dan mencapai $\geq 62,5 \%$; dan (5) Hasil belajar matematika siswa dikatakan berhasil jika hasil tes formatif minimum 75\% siswa mendapat nilai 60 atau lebih. Kriteria penilaian kualitas proses pembelajaran, yaitu: $\quad 1,00<$ Skor rata-rata $\leq 1,75=$ kurang

$1,75<$ Skor rata-rata $\leq 2,50=$ cukup

$2,50<$ Skor rata-rata $\leq 3,25=$ baik/aktif/senang

$3,25<$ Skor rata-rata $\leq 4,00=$ sangat baik/aktif/senang. 


\section{HASIL PENELITIAN DAN PEMBAHASAN Deskripsi Hasil Penelitian \\ a. Siklus pertama}

Pembelajaran dengan model Team Assisted Individualization pada siklus pertama dilakukan dalam dua pertemuan. Pada siklus ini mempelajari tentang operasi hitung bentuk aljabar dan pemfaktoran bentuk aljabar, dan diperoleh data seperti berikut.

\section{1) Data Aktivitas Diskusi Kelompok Siswa}

Pada siklus pertama pertemuan pertama diperoleh kelompok yang cukup aktif ada 4 kelompok, dan kelompok yang kurang aktif ada 3 kelompok. Sedangkan pada pertemuan kedua kelompok yang cukup aktif ada 5 kelompok dan 2 kelompok yang kurang aktif. Secara keseluruhan hasil pengamatan aktivitas diskusi kelompok pada siklus pertama baru mencapai $46,78 \%$. Aktivitas diskusi kelompok dikategorikan aktif apabila mencapai minimal 62,5\%.

Ada beberapa hal yang perlu diperbaiki, yaitu: (1) Pemberian motivasi oleh guru mengenai kerjasama siswa dalam kelompok belajar masih kurang; (2) Pengelolaan waktu yang belum efisien oleh guru, waktu untuk pengerjaan LKS terlalu lama sehingga waktu untuk mengerjakan LKS di depan kelas dan pembahasannya sedikit; (3) Pemberian bimbingan oleh guru yang belum merata; (4) Memotivasi siswa untuk aktif bertanya mengenai materi yang diajarkan; (5) Pengelolaan diskusi kelompok oleh guru masih kurang kondusif; dan (6) Pemberian materi yang berupa latihan pendalaman masih kurang.

2) Data Keterlibatan siswa Dalam Pembelajaran

Hasil pengamatan keterlibatan siswa dalam kegiatan pembelajaran pada siklus pertama mencapai 52,5\% dengan kriteria tergolong cukup baik. Keterlibatan siswa dalam pembelajaran dikategorikan baik apabila mencapai $62,5 \%$.

Ada beberapa hal yang perlu diperbaiki dalam masalah ini, yaitu: (1) Kesiapan dan perhatian siswa pada saat pemberian materi kurang; (2) Kerjasama siswa dalam kelompoknya belum aktif; (3) Keaktifan siswa untuk bertanya kepada guru sewaktu siswa mengerjakan LKS masih kurang; (4) Dalam pembahasan LKS pemberian tanggapan atas pertanyaan siswa lain masih kurang; dan (5) Siswa kurang aktif sewaktu membuat rangkuman dengan bimbingan guru.

3) Data Persepsi Siswa pada Kinerja guru

Persepsi siswa pada kinerja guru dalam kegiatan belajar mengajar pada siklus pertama secara keseluruhan masih dikategorikan kurang baik dengan perolehan skor hanya $41,87 \%$. Persepsi siswa pada kinerja guru dikategorikan baik apabila mencapai minimal $62,5 \%$.

4) Data sikap siswa pada pembelajaran Matematika

Hasil kuisioner tentang sikap siswa pada pembelajaran matematika dengan 10 pertanyaan pada siklus pertama dapat dikategorikan, bahwa siswa memiliki sikap positif pada model pembelajaran yang diterapkan, dengan skor mencapai $73 \%$. Pembelajaran matematika melalui model pembelajaran Team Assisted Individualization menyenangkan dan mudah diikuti. Hanya sebagian kecil siswa yang merasa pembelajaran dengan model pembelajaran Team Assisted Individualization berbantuan LKS membuat mereka bingung. Siswa merasa senang belajar secara kelompok. Penerapan pembelajaran seperti ini membuat mereka lebih berani untuk bertanya apabila ada materi yang belum dipahami.

5) Data Hasil Belajar Matematika

Hasil belajar matematika pada siklus pertama diperoleh memalui tes formatif dengan materi operasi hitung bentuk aljabar dan pemfaktoran bentuk aljabar. Hasil tes 
pada siklus pertama berdasarkan tiga aspek penilaian hasil belajar adalah sebagai berikut: (1) Aspek pemahaman konsep diperoleh siswa yang telah tuntas sebesar 80\%; (2) Aspek penalaran dan komunikasi diperoleh siswa yang telah tuntas sebesar 30\%; dan (3) Aspek pemecahan masalah diperoleh siswa yang telah tuntas sebesar 43,3\%.

\section{b. Siklus Kedua}

Pembelajaran pada siklus kedua dilakukan dalam dua pertemuan. Pembelajaran pada siklus kedua ini mempelajari tentang operasi hitung pecahan bentuk aljabar, dan diperoleh data sebagai berikut.

\section{1) Data Aktivitas Diskusi Kelompok Siswa}

Pada siklus kedua pertemuan pertama diperoleh kelompok yang aktif ada 1 kelompok, dan kelompok yang cukup aktif ada 6 kelompok. Sedangkan pada pertemuan kedua kelompok yang aktif ada 2 kelompok dan 5 kelompok lainnya cukup aktif. Secara keseluruhan hasil pengamatan aktivitas diskusi kelompok pada siklus kedua mencapai 59,12\%. Aktivitas diskusi kelompok dikategorikan aktif apabila mencapai minimal $62,5 \%$.

Ada beberapa hal yang perlu diperbaiki untuk siklus berikutnya, yaitu: (1) Pemberian motivasi oleh guru mengenai kerjasama siswa dalam kelompok belajar sudah baik namun harus ditingkatkan; (2) Pengelolaan waktu pembelajaran oleh guru mulai efisien, waktu untuk pengerjaan LKS dan mengerjakan LKS di depan kelas dan pembahasannya cukup; (3) Pemberian bimbingan oleh guru cukup merata dan harus ditingkatkan; (4) Pemberian motivasi kepada siswa untuk bertanya cukup baik; (5) Suasana diskusi kelompok belajar yang baik mulai tercipta; dan (6) Pemberian materi yang berupa latihan pendalaman masih kurang.

\section{2) Data Keterlibatan Siswa Dalam Pembelajaran}

Hasil pengamatan keterlibatan siswa dalam kegiatan pembelajaran siklus kedua mengalami peningkatan. Dengan perolehan skor pada siklus kedua secara keseluruhan mencapai $65 \%$ dengan kriteria termasuk ketegori baik.

Untuk mengoptimalkan tingkat keterlibatan siswa dalam pembelajaran, ada beberapa hal yang perlu diperbaiki diantaranya yaitu: (1) Keberanian siswa untuk mengerjakan hasil kerjanya didepan kelas perlu ditingkatkan yaitu dengan cara guru lebih memotivasi siswa; (2) Keaktifan siswa untuk bekerjasama dalam kelompok cukup baik namun harus terus ditingkatkan; (3) Keberanian siswa untuk bertanya kepada guru sewaktu siswa mengerjakan LKS cukup baik dan guru harus meningkatkan pemberian bimbingan apabila ada materi yang belum dipahami oleh siswa; dan (4) Dalam pembahasan LKS pemberian tanggapan atas pertanyaan siswa lain masih kurang.

\section{3) Data Persepsi Siswa pada Kinerja Guru}

Persepsi siswa pada kinerja guru dalam kegiatan pembelajaran pada siklus kedua mengalami peningkatan. Secara umum pada siklus kedua ini dapat disimpulkan kinerja guru mencapai $60 \%$ dan dapat dikategorikan tergolong cukup baik. Kinerja guru berdasarkan persepsi siswa dikatakan baik apabila mencapai 62,5\%.

\section{4) Data Sikap siswa pada pembelajaran Matematika}

Hasil kuisioner siswa terhadap pembelajaran pada siklus kedua respon siswa terhadap pembelajaran tergolong baik. Pembelajaran matematika menjadi lebih menarik dan menyenangkan melalui kerjasama belajar dalam kelompok. Ada beberapa peningkatan dari hasil kuisioner yang diberikan dan mencapai skor rata-rata $76 \%$. Pembelajaran matematika melalui model pembelajaran Team Assisted Individualization yang diterapkan sudah mulai mengarah pada model pembelajaran yang diharapkan. 


\section{5) Data Hasil Belajar Matematika}

Hasil belajar matematika pada siklus kedua diperoleh memalui tes formatif dengan materi operasi hitung pecahan dalam bentuk aljabar. Hasil tes pada siklus kedua berdasarkan tiga aspek penilaian hasil belajar diperoleh sebagai berikut: (1) pada aspek pemahaman konsep, siswa yang telah tuntas sebesar 56, 7\%; (2) pada aspek penalaran dan komunikasi, siswa yang telah tuntas sebesar 90\%; dan (3) pada aspek Pemecahan Masalah, siswa yang telah tuntas sebesar 76.7\%.

\section{c. Siklus Ketiga}

Pembelajaran pada siklus ketiga dilakukan dalam dua pertemuan. Pembelajaran pada siklus ketiga ini mempelajari tentang menyederhanakan bentuk aljabar dan pemfaktoran bentuk aljabar, dan diperoleh data seperti berikut.

\section{1) Data Aktivitas Diskusi Kelompok Siswa}

Pada siklus ketiga pertemuan pertama diperoleh kelompok yang aktif ada 3 kelompok, dan kelompok yang cukup aktif ada 4 kelompok. Sedangkan pada pertemuan kedua kelompok yang aktif ada 3 kelompok dan 4 kelompok yang cukup aktif. Aktivitas diskusi kelompok pada siklus ketiga secara umum diperoleh skor ratarata $60 \%$ dengan kriteria masih termasuk kategori cukup aktif. Aktivitas diskusi kelompok dikategorikan aktif apabila minmal mencapai $62,5 \%$.

Ada hal yang dapat dicermati dalam siklus ketiga ini yaitu: (1) Pemberian motivasi oleh guru mengenai kerjasama siswa dalam kelompok belajar cukup baik; (2) Pengelolaan waktu pembelajaran oleh guru sudah efisien; (3) Waktu untuk pengerjaan LKS, dan waktu mempresentasikan LKS di depan kelas serta pembahasannya cukup: (4) Pemberian bimbingan oleh guru cukup merata; dan (5) Pemberian materi yang berupa latihan pendalaman cukup.

\section{2) Data Keterlibatan Siswa Dalam Pembelajaran}

Hasil pengamatan keterlibatan siswa dalam kegiatan pembelajaran pada siklus ketiga mengalami peningkatan dari siklus-siklus sebelumnya. Dengan perolehan skor rata-rata mencapai $75 \%$ dengan kriteria tergolong baik.

Hal-hal yang dapat dicermati pada siklus ketiga, yaitu: (1) Siswa siap dan antusias untuk mengikuti pelajaran; (2) Keaktifan siswa untuk bekerjasama dalam kelompok baik; (3) Keberanian siswa untuk bertanya kepada guru dan maju ke depan kelas sewaktu siswa mengerjakan LKS cukup baik; dan (4) Suasana diskusi antarsiswa dalam kelompoknya berjalan dengan baik.

\section{3) Data Persepsi Siswa Pada Kinerja Guru}

Persepsi siswa pada kinerja guru dalam kegiatan belajar mengajar pada siklus ketiga tergolong baik. Secara umum pada siklus ketiga ini kinerja guru mencapai $68,75 \%$ dan dapat disimpulkan tergolong kategori baik.

4) Data Sikap siswa pada pembelajaran Matematika

Hasil kuisioner tentang sikap siswa terhadap pembelajaran pada siklus ketiga menunjukkan respon siswa terhadap pembelajaran tergolong baik. Pembelajaran matematika menjadi lebih menarik dan menyenangkan melalui kerjasama belajar dalam kelompok. Hasil kuisioner siklus ketiga mengalami sedikit penurunan persentase dari siklus sebelumnya yaitu hanya mencapai rata-rata $73,67 \%$. Pembelajaran matematika melalui model pembelajaran Team Assisted Individualization sudah lebih mengarah pada model pembelajaran yang efektif.

\section{5) Data Hasil Belajar Matematika}

Hasil belajar matematika pada siklus ketiga diperoleh memalui tes formatif dengan materi menyederhanakan bentuk aljabar. Hasil Tes Siklus ketiga berdasarkan 
tiga aspek penilaian hasil belajar diperoleh sebagai berikut: (1) Aspek pemahaman konsep diperoleh siswa yang telah tuntas sebesar 86.67\%; (2) Aspek penalaran dan komunikasi diperoleh siswa yang telah tuntas sebesar 80\%; dan (3) Aspek Pemecahan Masalah diperoleh siswa yang telah tuntas sebesar $83.33 \%$.

\section{Analisis Permasalahan}

a. Aktivitas Belajar Siswa

Pembelajaran matematika dengan model Team Assisted Individualization menempatkan siswa dalam kelompok-kelompok kecil (4 sampai 5 siswa) yang heterogen dan dilanjutkan dengan pemberian bantuan secara individu bagi siswa yang memerlukannya. Pelaksanaan pembelajaran dalam kelompok dapat berjalan dengan efektif jika siswa dalam kelompok aktif dan saling membantu.

Rata-rata aktivitas diskusi kelompok siswa pada pembelajaran matematika di siklus yang pertama secara umum hanya mencapai $46,78 \%$ dan termasuk kategori cukup aktif. Pada pertemuan pertama aktivitas diskusi kelompok kurang aktif, namun kekurangan-kekurangan yang terjadi pada pertemuan pertama dapat diperbaiki pada pembelajaran pertemuan kedua.

Pada siklus kedua aktivitas diskusi kelompok siswa meningkat dan mencapai $59,12 \%$ sedangkan pada siklus ketiga aktivitas diskusi kelompok siswa mencapai $60 \%$. Aktivitas diskusi kelompok siswa secara keseluruhan dari siklus pertama sampai siklus ketiga dapat dilihat pada gambar berikut.

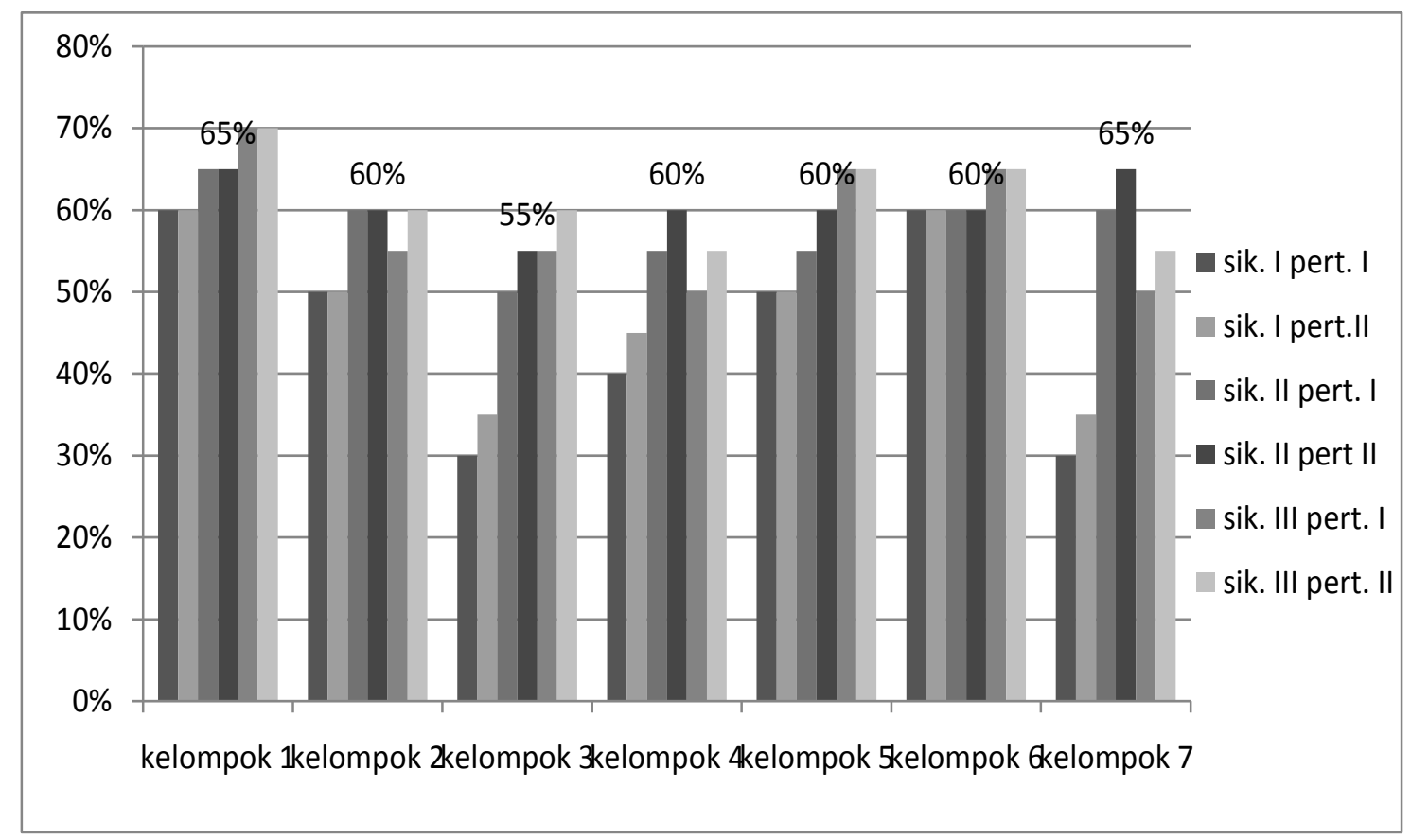

Gambar 1.

Aktivitas Belajar Siswa Dalam Diskusi Kelompok

Siklus I, siklus II dan siklus III

Dari gambar aktivitas diskusi kelompok siswa dapat dilihat bahwa dalam pembelajaran pada siklus I, siklus II dan siklus III kelompok yang dapat dikatagorikan aktif cukup sedikit. Kondisi ini dapat terjadi disebabkan oleh: 
1) Pada awal-awal pembelajaran matematika dengan model Team Assisted individualization sebagian siswa belum terbiasa dengan kondisi belajar berkelompok.

2) Sebagian kelompok belum memahami langkah-langkah pembelajaran model Team Assisted Individualization secara utuh dan menyeluruh sehingga siswa belum memahami peran dan tugasnya dalam bekerja kelompok.

3) Interaksi antar siswa belum berjalan dengan baik karena siswa belum terbiasa untuk menyampaikan pendapatnya kepada sesama teman lainnya dalam menyelesaikan masalah.

4) Dalam diskusi kelompok masih didominasi oleh siswa yang pandai sehingga sebagian siswa masih bertindak pasif dan menggantungkan permasalahan yang dihadapi kepada kelompoknya.

5) Guru belum bisa mengorganisasikan waktu dengan baik, karena waktu untuk mengerjakan LKS terlalu lama sehingga waktu untuk presentasi hasil karya kelompok terbatas.

6) Guru dalam memberikan bimbingan belum merata, guru hanya memberikan bimbingan pada kelompok yang aktif bertanya saja.

Untuk mengatasi masalah diatas dilakukan upaya-upaya sebagai berikut :

1) Guru dengan intensif memberi pengertian kepada siswa kondisi dalam pembelajaran berkelompok, kerjasama kelompok, dan keterlibatan siswa dalam kelompok.

2) Guru membantu kelompok yang belum memahami langkah-langkah pembelajaran model Team Assisted Individualization.

3) Guru akan berusaha memberikan bimbingan secara merata kepada siswa.

4) Guru memberi teguran kepada siswa yang pasif dalam diskusi kelompok belajar.

5) Menjaga agar aktivitas diskusi kelompok berjalan dengan baik sehingga tercipta kondisi belajar yang kondusif dan efektif.

6) Pengelolaan waktu pembelajaran akan dievaluasi untuk lebih mengefektifkan kegiatan belajar.

\section{b. Keterlibatan Siswa Dalam Pembelajaran}

Keterlibatan siswa atau aktivitas siswa dalam pembelajaran matematika model Team Assisted Individualization diambil dari lembar pengamatan yang dicatat oleh guru pengamat. Keterlibatan atau aktivitas siswa dalam pembelajaan dapat dikatakan dengan baik bila mencapai persentase $62,5 \%$.

Pada siklus yang pertama hasil pengamatan aktivitas siswa dalam pembelajaran tergolong cukup baik dengan perolehan skor pada pertemuan pertama 20 dan pada pertemuan kedua 22. Secara umum persentase keterlibatan siswa dalam pembelajaran pada siklus pertama mencapai 52,5\% dengan kriteria kinerja siswa dalam pembelajaran cukup baik.

Hasil pengamatan aktivitas siswa dalam pembelajaran pada siklus kedua mengalami peningkatan. Dengan perolehan skor pada pertemuan pertama 24 kinerja siswa dapat dikatakan cukup baik dan pada pertemuan kedua 28 kinerja siswa dapat dikatakan baik. Secara keseluruhan persentase kinerja siswa pada siklus II mencapai 65\% dengan skor rata-rata 2,6 kriteria kinerja siswa dalam pembelajaran baik.

Hasil pengamatan aktivitas siswa dalam pembelajaran pada siklus ketiga mengalami peningkatan dari siklus-siklus sebelumnya. Dengan perolehan skor pada pertemuan pertama 29 kriteria kinerja siswa dapat dikatakan baik dan pada pertemuan kedua mendapat skor 31 kinerja siswa dapat dikatakan baik. Secara umum persentase kinerja siswa pada siklus III mencapai $75 \%$ dengan skor rata-rata 3,0 kriteria kinerja siswa dalam pembelajaran baik. 


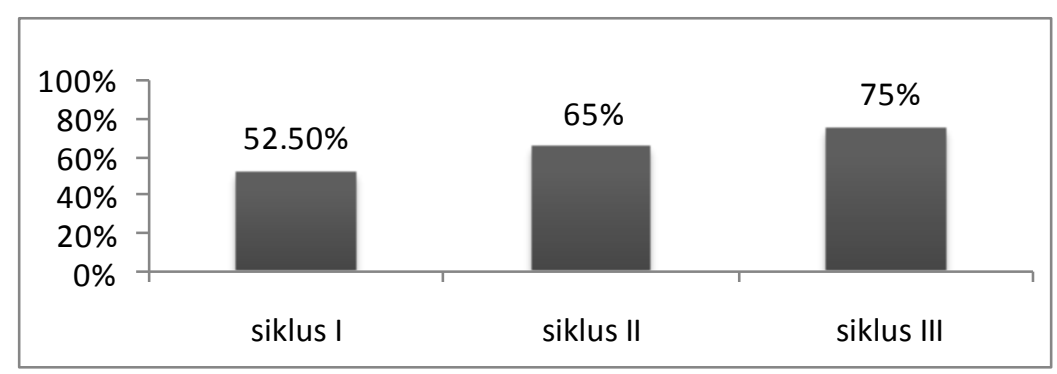

Gambar 2.

Aktivitas Siswa Dalam Pembelajaran Siklus I, II, dan III

Dari gambar 2. keterlibatan atau aktivitas siswa dalam pembelajaran pada siklus yang pertama belum dapat dikatagorikan baik. Kesiapan dan perhatian siswa pada saat pemberian materi kurang, kerjasama siswa dalam kelompoknya masih belum aktif, keaktifan siswa untuk bertanya kepada guru sewaktu siswa mengerjakan LKS masih kurang, dalam pembahasan LKS pemberian tanggapan atas pertanyaan siswa lain masih kurang, siswa kurang aktif sewaktu membuat rangkuman dengan bimbingan guru. Kekurangan yang terjadi pada pembelajaran siklus pertama terus diperbaiki agar siswa lebih aktif untuk belajar.

Pada siklus yang kedua dan siklus ketiga keterlibatan atau aktivitas siswa dalam pembelajaran dapat dikatagorikan baik. Siswa siap dan antusias untuk mengikuti pelajaran, keaktifan siswa untuk bekerjasama dalam kelompok baik. Siswa berani untuk bertanya kepada guru, suasana diskusi antarsiswa dalam kelompoknya berjalan dengan baik.

\section{c. Persepsi Siswa Pada Kinerja Guru}

Persepsi siswa terhadap kinerja guru diambil dari lembar pengamatan yang dicatat oleh guru pengamat. Persepsi siswa pada kinerja guru dikatakan baik bila mencapai persentase $62,5 \%$. Hasil pengamatan kinerja guru dalam pembelajaran siklus pertama pertemuan pertama masih tergolong rendah. dengan skor kemampuan guru dalam pengelolaan pembelajaran sebesar 28 kriteria persepsi siswa pada kinerja guru kurang baik. Sedangkan pada pertemuan kedua terdapat peningkatan, dengan skor 39 dengan kriteria kinerja guru cukup baik. Namun secara keseluruhan pada siklus pertama ini kinerja guru masih kurang baik dengan persentase kinerja guru hanya mencapai $41,87 \%$.

Pada pembelajaran siklus yang kedua dilakukan upaya untuk memperbaiki kekurangan pada pembelajaran sebelumnya, salah satu caranya dengan meningkatkan kinerja guru dalam pengelolaan pembelajaran. Hasil pengamatan persepsi siswa pada kinerja guru dalam pembelajaran pada siklus yang kedua mengalami peningkatan. Pada pertemuan pertama mendapat skor 47 dengan kriteria kinerja guru cukup baik dan pada pertemuan kedua kinerja guru tergolong cukup baik dengan skor kemampuan guru dalam pengelolaan pembelajaran sebesar 49. Secara umum pada siklus kedua ini dapat disimpulkan kinerja guru cukup baik dengan skor rata-rata 2,4 persentase kinerja guru mencapai $60 \%$.

Hasil pengamatan persepsi siswa pada kinerja guru dalam pembelajaran pada siklus yang ketiga tergolong baik. Pada pertemuan pertama mendapat skor 53 dan pertemuan kedua dengan skor kemampuan guru dalam pengelolaan pembelajaran sebesar 57. Secara umum pada siklus ketiga ini dapat disimpulkan kinerja guru baik dengan skor rata-rata 2,75 dan persentase kinerja guru mencapai $68,75 \%$. 


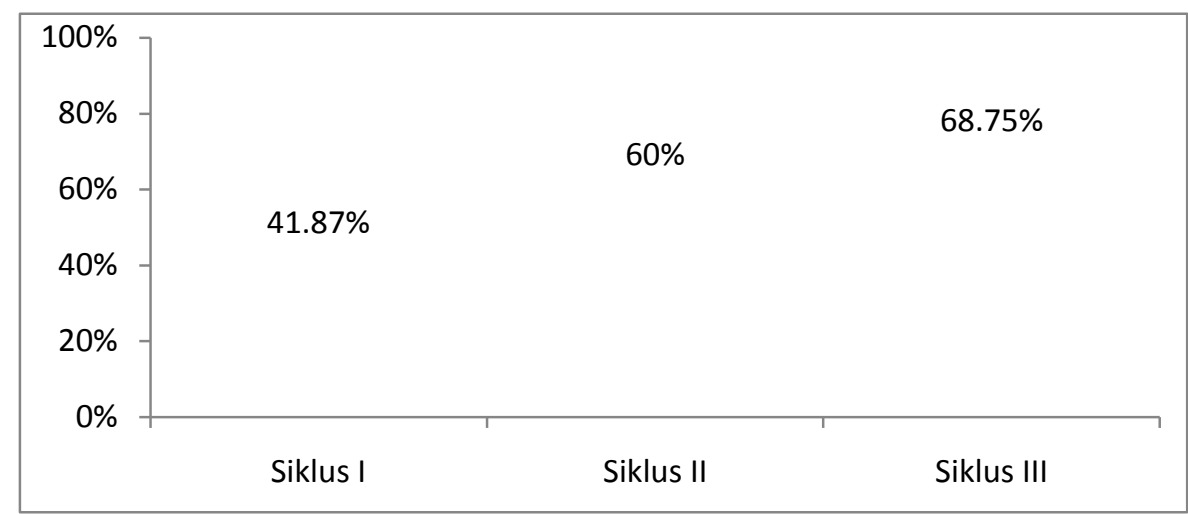

Gambar 3

Persepsi Siswa Pada Kinerja Guru

Dari gambar 3 dapat dilihat persepsi siswa terhadap kinerja guru disiklus yang pertama kurang baik. Hal ini terjadi karena guru masih beradaptasi dengan model pembelajaran Team Assisted Individualization. Kinerja guru yang teramati dan harus diperbaiki pada pembelajaran siklus yang pertama adalah sebagai berikut :

1) Guru belum mampu memberikan motivasi kepada siswa ini terlihat dari kurang semangatnya siswa dalam pembelajaran.

2) Ketrampilan guru dalam cara pengelolaan kelas kurang baik, banyak siswa yang bicara sendiri dan tidak mendengarkan penjelasan dari guru.

3) Cara guru memberikan arahan dan bimbingan kelompok kepada siswa kurang baik, guru hanya memberikan bimbingan terhadap kelompok yang aktif saja.

4) Pemerataan perhatian guru dalam memberikan bimbingan kepada siswa selama proses belajar mengajar berlangsung kurang baik, guru hanya memperhatikan siswa yang aktif saja.

5) Ketepatan waktu yang diperlukan guru dalam menyampaikan materi kurang baik, waktu untuk mengerjakan LKS secara kelompok lebih lama sehingga untuk presentasi hasil karya kelompok hanya beberapa kelompok saja yang presentasi.

6) Guru dalam menyampaikan refleksi pembelajaran kurang baik, guru menyimpulkan sendiri tentang materi yang baru saja dijelaskan.

Pada pembelajaran siklus yang kedua terjadi peningkatan kinerja guru yang mencapai $60 \%$ dengan kriteria persepsi siswa pada kinerja guru cukup baik, namun masih dibawah kriteria katagori baik yang diharapkan yaitu persentase harus mencapai $62,5 \%$. Sedangkan pada pembelajaran siklus ketiga persepsi siswa pada kinerja guru dapat dikatakan baik dengan persentase mencapai $68,75 \%$.

\section{d. Sikap Siswa Pada Pembelajaran Matematika}

Berdasarkan hasil kuisioner pada siklus yang pertama dari 10 pertanyaan yang diberikan dan telah diisi oleh siswa ternyata rata-rata siswa bersikap positif pada model pembelajaran yang diterapkan, persentasenya mencapai $73 \%$. Siswa dikatakan merasa senang terhadap pembelajaran apabila rata-rata hasil kuisioner yang diisi siswa menunjukkan persentase $70 \%$ atau lebih.

Berdasarkan hasil kuisioner siswa terhadap pembelajaran pada siklus yang kedua respon siswa terhadap pembelajaran baik yaitu mencapai rata-rata $76 \%$. Sedangkan hasil kuisioner siswaterhadap pembelajaran disiklus yang ketiga mengalami penurunan persentase dari siklus sebelumnya yaitu hanya mencapai rata-rata $73,67 \%$. 


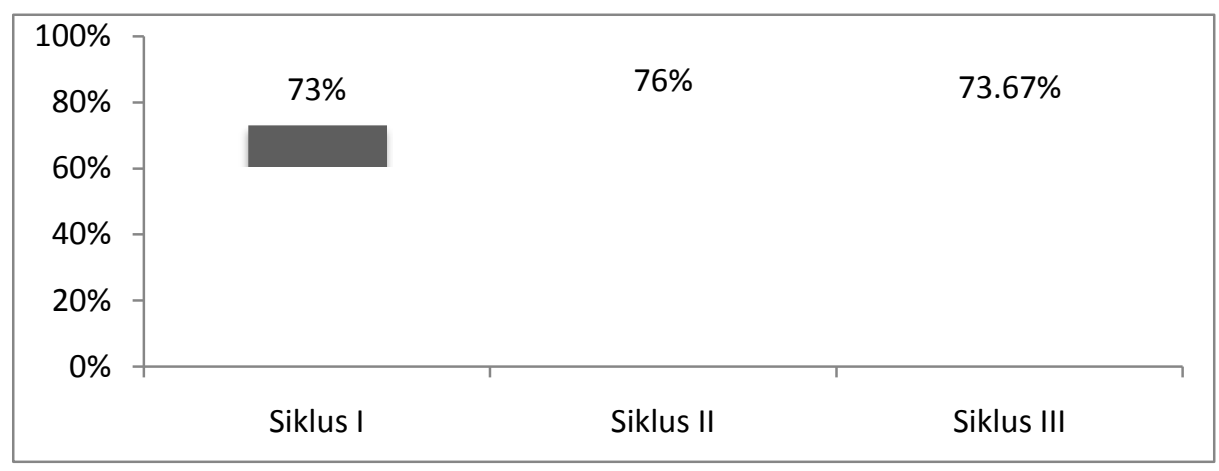

Gambar 4.

Sikap Siswa Pada Pembelajaran Matematika

Pada pembelajaran siklus yang pertama ada sebagian siswa yang merasa pembelajaran dengan model pembelajaran Team Assisted Individualization berbantuan LKS membuat mereka bingung. Namun banyak juga siswa yang beranggapan pembelajaran matematika melalui model pembelajaran Team Assisted Individualization menyenangkan dan mudah diikuti. Siswa merasa senang belajar secara kelompok. Penerapan pembelajaran seperti ini membuat mereka lebih berani untuk bertanya apabila ada materi yang belum dipahami.

Pembelajaran matematika melalui model pembelajaran Team Assisted Individualization yang diterapkan pada siklus yang kedua sudah mulai mengarah pada model pembelajaran yang diharapkan. Namun masih perlu ada perbaikan dan upaya untuk meningkatkan proses pembelajaran. Hasil kuisioner siswa terhadap pembelajaran pada siklus yang ketiga respon siswa terhadap pembelajaran baik, walaupun terjadi penurunan persentase dari siklus sebelumnya. Pembelajaran matematika menjadi lebih menarik dan menyenangkan melalui kerjasama belajar dalam kelompok. Pembelajaran matematika melalui model pembelajaran Team Assisted Individualization sudah lebih mengarah pada model pembelajaran. Namun masih perlu ada perbaikan dan upaya untuk meningkatkan proses pembelajaran yang sesuai dengan kebutuhan siswa.

\section{e. Analisis Hasil Belajar Matematika}

Hasil belajar siswa setelah melakukan pembelajaran matematika melalui model pembelajaran Team Assisted Individualization diukur melalui tes formatif yang dilakukan pada akhir tiap siklus. Hasil belajar matematika siswa dikatakan berhasil jika hasil tes formatif minimum $75 \%$ dari seluruh siswa mendapat nilai 60 atau lebih.

Hasil tes formatif pada siklus pertama dapat disimpulkan belum berhasil karena hanya mencapai rata-rata 51,5\% siswa yang telah tuntas. Dari tiga aspek penilaian baru aspek pemahaman konsep dapat dikatakan berhasil yaitu persentase siswa yang sudah tuntas mencapai $80 \%$, sedangkan aspek penalaran dan komunikasi belum berhasil persentase siswa yang telah tuntas hanya mencapai $30 \%$ dan aspek pemecahan masalah persentase siswa yang telah tuntas adalah $43,3 \%$.

Hasil tes formatif pada siklus yang kedua dapat dikatakan belum berhasil karena hanya mencapai rata-rata $74,4 \%$ siswa yang telah tuntas. Dari tiga aspek penilaian, aspek pemahaman konsep dikatakan tidak berhasil karena persentase siswa yang sudah tuntas hanya mencapai $56,7 \%$, sedangkan aspek penalaran dan komunikasi dikatakan berhasil dengan persentase siswa yang telah tuntas mencapai $90 \%$ dan aspek pemecahan masalah persentase siswa yang telah tuntas adalah $76,7 \%$

Hasil tes formatif pada siklus ketiga mencapai rata-rata 83,3\% siswa yang telah tuntas dan dapat dikatakan berhasil. Dari tiga aspek penilaian, aspek pemahaman konsep 
dapat dikatakan berhasil yaitu persentase siswa yang sudah tuntas mencapai 86,7\%, sedangkan aspek penalaran dan komunikasi berhasil dengan persentase siswa yang telah tuntas mencapai $80 \%$ dan aspek pemecahan masalah berhasil dengan persentase siswa yang telah tuntas adalah $83,3 \%$.

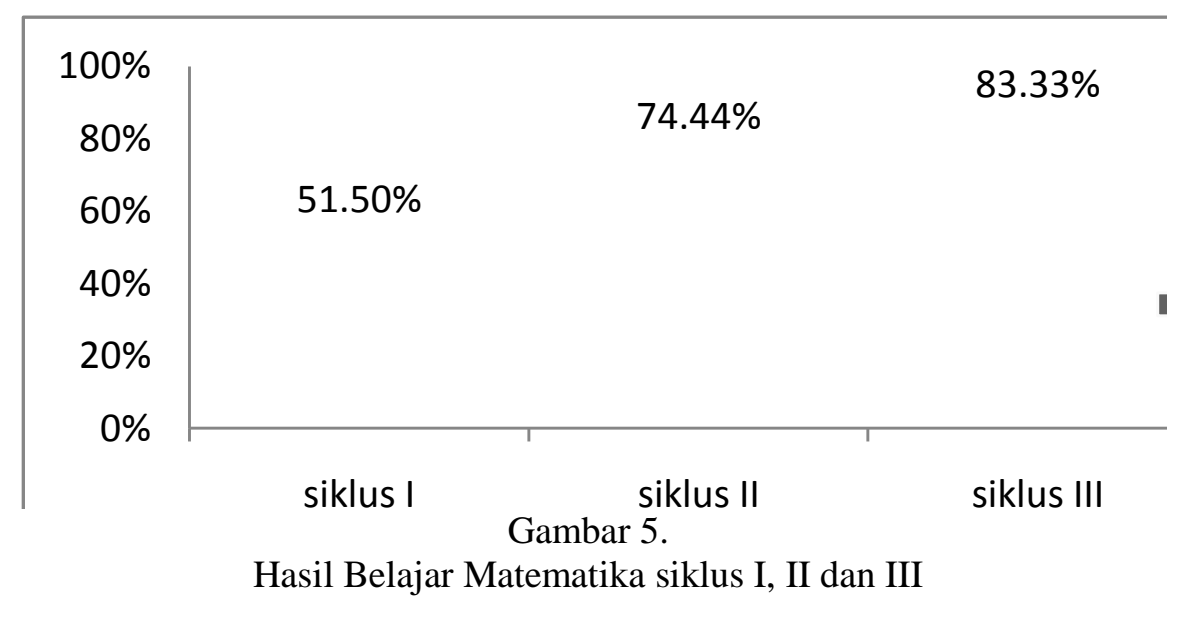

\section{Pembahasan Hasil Penelitian}

Secara umum kualitas proses pembelajaran dan hasil belajar matematika dapat ditingkatkan melalui penggunaan model pembelajaran Team Assisted Individualization. Pembelajaran matematika dilakukan untuk materi aljabar pada siswa kelas VIII. Kualitas proses pembelajaran diwakili dengan beberapa aspek yaitu: aktifitas diskusi kelompok siswa, keterlibatan siswa dalam pembelajaran persepsi siswa pada kinerja guru, dan sikap siswa pada pembelajaran matematika. Secara umum model pembelajaran Team Assisted Individualization dapat merangsang siswa untuk lebih aktif dan terlibat dalam pembelajaran matematika. Model pembelajaran ini dapat menggairahkan siswa dalam belajar. Siswa merasa senang dan memeiliki pandangan positif pada pembelajaran matematika. Melalui model pembelajaran ini, siswa dapat berbagi dan saling mengisi satu sama lain, sehingga masalah-masalah yang tidak dapat dipecahkan sendirian dapat dipecahkan melalui diskusi kelompok. Hal ini sejalan dengan pendapat Slavin (2010:195) yang mengatakan bahwa, "Model pembelajaran Team Assisted Individualization dirancang untuk menyelesaikan masalah-masalah teoritik dan praktik dari sistem pengajaran individual."

Hasil belajar matematika dalam penelitian ini ditinjau dari 3 (tiga) aspek, yaitu: aspek pemahaman konsep, aspek penalaran dan komunikasi, dan aspek pemecahan masalah matematika. Secara umum hasil belajar matematika untuk materi aljabar mengalami peningkatan dari siklus pertama hingga siklus ketiga dengan persentase siswa yang tuntas pada siklus pertama 51,50\%, siklus kedua 74,44\%, dan siklus ketiga 83,33\%. Hal ini terjadi karena melalui penerapan model pembelajaran Team Assisted Individualization hambatan-hambatan siswa dalam belajar dapat dieliminasi.

Pembelajaran Team Assisted Individualization merupakan salah satu model pembelajaran kooperatif. Trianto (2010:56) menyatakan, bahwa pembelajaran kooperatif dilakukan dengan tujuan untuk memaksimalkan belajar siswa dalam upaya peningkatan prestasi akademik dan pemahaman baik secara individu maupun secara kelompok. Melalui model pembelajaran Team Assisted Individualization siswa yang belum paham tidak merasa malu untuk bertanya pada tamannya, dan demikian pun keberanian siswa untuk tampil memecahkan masalah semakin berani untuk tamil di depan kelas. Siswa merasa tertarik dan menikmati belajar matematika. Sehingga sangatlah wajar kalau akhirnya hasil belajar matematika pun menjadi meningkat. 


\section{PENUTUP}

\section{Kesimpulan}

Hasil penelitian dapat menyimpulkan, bahwa: (1) Melalui penggunaan model pembelajaran Team Assised Individualization kualitas proses pembelajaran matematika yang meliputi aktivitas diskusi kelompok, keterlibatan siswa dalam belajar, persepsi siswa pada kinerja guru, dan sikap siswa pada pembelajaran matematika dapat ditingkatkan. (2) Secara umum hasil belajar matematika untuk materi aljabar meningkat melalui enerapan model pembelajaran Team Assisted Individualization.

\section{Saran}

Model pembelajaran Team Assited Individualization dapat digunakan sebagai salah satu alternatif model pembelajaran yang efektif untuk meningkatkan proses dan hasil belajar matematika untuk materi aljabar.

\section{DAFTAR PUSTAKA}

Adinawan, M.Cholik dan Sugijono. 2007. Matematika Untuk SMP/MTs Kelas 8. Jakarta, Erlangga.

Alwi, Hasan. 2002. Kamus Besar Bahasa Indonesia. Jakarta, Balai Pustaka.

Dimyati dan Mujiono. 2006. Belajar dan Pembelajaran. Jakarta, PT. Rineka Cipta.

Djamarah, Syaiful Bahri. 2002. Psikologi Belajar. Jakarta, PT. Rineka Cipta.

Hamalik, Oemar. 2010. Proses Belajar Mengajar. Jakarta, PT. Bumi Aksara.

Hudoyo, Herman. 1988. Mengajar Belajar Matematika. Jakarta, Depdikbud.

Kirkpatrick, Donald L. and James D. Kirkpatrick. 2006. Evaluating Training Programs. San Fransisco, Berrett-Koehler Publishers Inc.

Purwanto, Ngalim.2004. Psikologi Pendidikan. Bandung, Remaja Rosda Karya.

Purwodarminto. 1976. Kamus Umum Bahasa Indonesia. Jakarta, Balai Pustaka.

Russefendi. 1990. Pengajaran Matematika Modern Untuk Guru. Bandung, Tarsito.

Sardiman. 1986. Interaksi dan Motivasi Belajar Mengajar. Jakarta, CV. Rajawali.

Slameto. 2010. Belajar dan Faktor-faktor Yang Mempengaruhi. Jakarta, PT. Rineka Cipta.

Slavin, Robert E. 2010. Cooperative Learning Teori, Riset dan Praktik. Bandung, Nusa Media.

Sudjana, Nana. 2009. Penilaian Proses dan Hasil Belajar Mengajar. Bandung, PT. Remaja Rosdakarya.

Suryanto, Adi, dan Tedjo Djatmiko. 2009. Evaluasi Pembelajaran di SD. Jakarta, Universitas Terbuka.

Syah, Darwyan, Supardi dan Eneng Muslihah. 2009. Strategi Belajar Mengajar. Jakarta, Diadit Media.

Syah, Muhibbin. 2004. Psikologi Belajar. Jakarta, PT. Raja Grafindo Persada.

Trianto. 2010. Mendesain Model Pembelajaran Inovatif Progresif. Jakarta, Kencana.

Yamin, H. Martinis. 2005. Strategi Pembelajaran Berbasis Kompetensi. Jakarta, Gaung Persada. 